\author{
Elena Savelieva \\ Nyugat-magyarországi Egyetem \\ Savaria Egyetemi Központ, Szombathely
}

\title{
Glagoli premikanja v frazemih slovenskega knjiznega jezika
}

Prispevek obravnava frazeme z glagolsko sestavino premikanja in jih analizira s tematskega vidika. Poskuša odgovoriti na vprašanje, katere pojme tematizirajo frazemi s tovrstno sestavino, kakšno je razmerje med pomenom sestavin ( $\mathrm{v}$ tem primeru glagola premikanja) in celotnim pomenom frazema in kateri glagoli premikanja imajo večjo vlogo pri frazeologizaciji posameznih pojmov.

The paper treats phrasemes containing verbs of motion and analyzes them from a thematic viewpoint. It attempts to answer the question as to what notions are thematicized by the phrasemes of this type, as well as the relationship between the meaning of the elements (in this case, verbs of motion) and the phraseme as a whole and which verbs of motion play a greater role in the phraseologization of individual notions.

\section{Uvod}

Veliko število glagolov s skupnim pomenom 'premikati se' potrjuje dejstvo, da je premikanje eden izmed osnovnih človekovih življenjskih potreb. ${ }^{1}$ Predpostavljamo, da imajo glagoli premikanja tudi pri frazeologizaciji pomembno vlogo.

$\mathrm{V}$ prispevku sem se omejila predvsem na premikanje v prostoru in času oz. na premikanje, ki pomeni premagovanje poti. Upoštevala sem temeljne glagole premikanja, ki jih glede na determiniranost ali nedeterminiranost v svoji slovnici parno izpostavlja Jože Toporišič (2000: 351): nesem - nosim, peljem/vedem - vodim, peljem - vozim, jaham - jezdim, ženem - gonim, tečem - tekam, letim - letam, bežim - begam, lezem - lazim, grem - hodim, vlečem - vlačim, bredem - brodim, njihove možne predponske oblike pa so bile zbrane iz elektronske izdaje Slovarja slovenskega knjižnega jezika. Pri iskanju glagolov sem izhajala predvsem iz izhodiščnega glagola premikati se. V polje razlaga $\mathrm{V}$ okviru zahtvnega iskanja elektronske verzije SSKJ sem vpisala najprej glagol premikati $s e^{2}$ in dobila izpis vseh glagolov, ki imajo ta glagol kot razlagalno pomensko sestavino. $\mathrm{Na}$ ta način sem dobila, npr. glagole drveti, hiteti, hoditi, iti, teči itd. Nato sem v polje

\footnotetext{
${ }^{1}$ Članek se navezuje na magistrsko delo Koncept premikanja in glagoli premikanja $v$ frazemih slovenskega knjižnega jezika, Oddelek za slovanske jezike in književnosti Filozofske Fakultete Univerze v Mariboru, 2008, mentorica red. prof. dr. Irena Stramljič Breznik. Iskreno se zahvaljujem dr. Ireni Stramljič Breznik za kritičen pregled in strokovne napotke pri pripravljanju tega prispevka.

${ }^{2}$ Upoštevala sem povratni glagol premikati se predvsem zato, ker prav ta glagol pomeni premikanje človeka $\mathrm{v}$ prostoru iz ene točke $\mathrm{v}$ drugo.
} 
razlaga vpisovala po vrsti vsak glagol iz prve skupine. Tako se npr. glagol teči pojavi kot razlagalna sestavina pri glagolih cvirnati, dirjastiti, galopirati, loviti se, tekati. Ko sem pregledala vsak glagol iz druge skupine, sem dobila tretjo, npr. glagol tekati je razlagalna sestavina glagolov frkati, furijati, poditi se, pofrfotavati, švrkati, teklja$t i$, vrtoglaviti itd. Na koncu sem $\mathrm{v}$ isto polje vpisovala glagole iz tretje skupine itd. Upoštevaje hierarhično pomenskosestavinsko strukturo pri slovarski razlagi glagolov po načelu, da so temeljni glagoli vselej vključeni v razlago pomensko specifičnejših (Žele 2001), sem izdelala zelo gosto mrežo glagolov premikanja, saj je takih glagolov s pomensko sestavino premikati se več kot osemsto. Ti pa so bili nato preizkušeni še $\mathrm{v}$ frazeološke namene.

Tudi frazeme sem iskala v elektronski verziji SSKJ, tako da sem v polje razlaga po vrsti vpisovala glagole premikanja, in sicer s predponami in brez predpon. Iskanje glagolov in frazemov je večinoma potekalo hkrati.

V prispevku so analizirani frazemi v ožjem smislu (zrasleki, sklopi) ter kolokacije (skupi in primerjalni frazemi). ${ }^{3}$ Spodnjo mejo frazemov predstavljajo enote, $v$ katerih je ena izmed sestavin nepolnopomenska beseda, npr. predlog (priti do), zgornjo mejo predstavljajo enote, $\mathrm{v}$ katerih je mesto osebka zapolnjeno s sestavino frazema, imajo pa prosto desno vezljivostno mesto, v katerem nastopa vršilec, nosilec stanja ali lastnosti (voda komu v grlo teče). Niso pa bili obravnavani pragmatični frazemi z glagolski sestavino (npr. pojdi se solit!). ${ }^{4}$ Pri ugotavljanju, ali gre v primerih, zbranih iz SSKJ, res za frazem, sem si pomagala z besedilnim korpusom Nova beseda. ${ }^{5}$ Vsako posamezno sobesedilo, v katerem se je pojavil iskani frazem, sem v korpusu posebej preverila, saj se v razpoložljivem konkordančnem nizu včasih težko določi, ali gre za preneseni ali dobesedni pomen. Upoštevala sem tudi mnenje korpusnih raziskovalcev, ki poročajo o visoki leksikalni variantnosti in ustaljenih pretvorbah posameznega frazema (Gantar 2003: 213; 2007).

Tako zbranim frazemom je sledila njihova tipologizacija. Pokazalo se je, da se pojavljata dve veliki skupini frazemov. V prvi nastopajo frazemi z glagolom premikanja, ki dejansko izražajo koncept premikanja, in sicer način premikanja (hoditi $k$ nogam, iti k nogam) in lastnost premikanja: težko (komaj vleči noge za seboj), lahkotno (hoditi/iti kot srna), ponosno (hoditi kot/kakor pav), ponižno (oditi/odvleči se kot potepe/pretepen pes) ali previdno (hoditi kot/kakor po jajcih) premikanje. Med glagoli so najpogosteje zastopani hoditi, teči iti in bežati. ${ }^{6} \mathrm{~V}$ drugi skupini so predstavljeni

${ }^{3}$ Frazemi so besedne zveze, katerih značilnosti so: (1) najmanj dvobesednost; (2) neizpeljivost njihovega pomena iz pomena sestavin, (3) stalnost, (4) reproduciranost, (4) relativna stalnost ter ekspresivnost v razmerju do prostih besednih zvez (Stramljič Breznik 1999: 264).

${ }^{4}$ Pragmatični frazemi z glagolski sestavino (npr. pojdi se solit!) so bili temeljito pregledani in analizirani v delih Irene Stramljič Breznik (2000/01) in Nataše Jakop (2002, 2005, 2006).

${ }^{5}$ Iskanje frazemov je potekalo v letih 2003-2004. Takrat je bil prostodostopen le ta korpus, ki je imel aktualnejše gradivo kot Fida. Upoštevati pa moramo dejstvo, da so se lahko podatki spremenili, nekateri frazemi so zastareli, raba nekaterih pa se je povečala.

${ }^{6}$ Tovrstni frazemi so bili skupaj s frazemi brez glagolske sestavine premikanja, ki sicer pomenijo premikanje, podrobno analizirani v Elena Savelieva (2007), Koncept premikanja in glagoli premikanja v frazemih slovenskega knjižnega jezika, Magistrsko delo, Maribor oz. 
frazemi, ki vsebujejo glagole premikanja, vendar ne pomenijo premikanja, ampak najpogosteje govore o lastnostih človeka kot živega bitja oz. o njegovem obstajanju in udejanjanju v družbi. Prav tem bo v nadaljevanju posvečena vsa pozornost.

\section{Tematska klasifikacija frazemov $z$ glagolsko sestavino premikanja}

1.1 V zadnjem času se $\mathrm{v}$ tujem jezikoslovju pojavlja vedno več literature, $\mathrm{v}$ kateri avtorji, izhajajoč iz slike sveta določene jezikovne skupnosti, sistematizirajo leksikon posameznega jezika. Podobne težnje so prisotne tudi v frazeologiji (Telia 1995, Mirsaetova 2004, Bańczerowski 2000, 2007). Številne raziskave se ukvarjajo s temami, ki so neposredno povezane s človekovo dejavnostjo ali njegovimi lastnost$\mathrm{mi}$; to je pogojeno $\mathrm{z}$ antropocentričnim načelom preučevanja frazeologije. Kot rezultat nastajajo tudi frazeološki ideografski slovarji. Med slovanskimi jeziki je poljščina dobila prvi taki frazeološki tematski slovar, ki sta ga leta 1966 sestavili Iglikowska in Kurkowska. Med ruskojezičnimi frazeološkimi slovarji je znan tak slovar Jaranceva (1997, 2001). Leta 1999 je izšel tematski frazeološki slovar ruskega jezika (lastnosti človeka), ki ga je napisala Anke Levin-Steinmann. Pri delitvi makroteme na posamezne teme in podteme je pomembna čim večja natančnost. Toda kljub prizadevanju, biti dosleden in objektiven pri določitvi tematskih mej, se ne moremo izogniti subjektivnemu vidiku, in sicer vidiku avtorja, kakor meni Anke Levin-Steinmann. Dokaz so številne klasifikacije različnih avtorjev, ki v nekaterih točkah sovpadajo, v drugih pa se popolnoma razhajajo, npr. Aksamitov (1987: 52), Ivčenko (1987: 19), Solodub (1985: 90) (po A. Levin-Steinmann 1999: 11). Nezmožnost, ostati popolnoma objektiven, je pogojena tudi z drugimi dejavniki. Avtorica slovarja (Levin-Steinmann 1999: 12) navaja tu trditvi Karaulova, da je »vsaka beseda $\mathrm{z}$ deseterimi in stotimi nitmi povezana s pomeni mnogih drugih « in da izolirane, zaprte skupine ne obstajajo, kot ne obstajajo izolirane besede.

Kabanova (1996) podaja strukturo tematskega sklopa, ki je videti takole:

Frazemi, ki se razlikujejo v stopnji ekspresivnosti in čustvenosti, v dodatnih odtenkih ali obsegu pomena, tvorijo sinonimno vrsto. Sinonimne vrste tvorijo pomenske skupine. Frazemi, pripadajoči istemu krogu predstav, pojmov, ki so si podobni ali nasprotni v svojem pomenu, se združujejo v pomenska polja, znotraj katerega so značilna razmerja sinonimije, variantnosti in antonimije med enotami (Kabanova 1996: 113-114). Pomenska polja, ki so povezana $\mathrm{z}$ isto temo, se združujejo v makropolja, tj. tematske skupine. ${ }^{7}$ To lahko ponazorimo takole, npr. frazema iti na živce, iti komu na jetra sta del širše sinonimne vrste frazemov, ki tvorijo pomensko skupino »čustva - odnosi«, znotraj nje nastopa pomensko polje »čustva«, kar je del tematske skupine »notranji svet človeka« oz. makropolja »človek«.

1.2 Frazemi z glagolsko sestavino premikanja se navezujejo na človeka, zato sem jih razvrstila na podlagi klasifikacije Nikitine (1995: 78), ki je v svoji razpravi

Elena Savelieva Frazemi s pomenom »premikati se«v slovenskem knjižnem jeziku. Oddano v objavo.

${ }^{7}$ Podroben pregled poimenovanj za pomensko organizirane besedne združbe v slovenskem jezikoslovju je podan v prispevku Irene Stramljič Breznik (2006, 285-300). 
natančno predstavlila tematsko skupino »človek«. Skupine frazemov, z določenim skupnim pomenom, niso popolne, saj imajo posamezne rubrike lahko več frazemov, ki ne vsebujejo glagola premikanja. Zbir tovrstnih skupin in njihova natančna pomenska, motivacijska in strukturna analiza predstavljajo nov izziv pri raziskovanju slovenske frazeologije. ${ }^{8}$

Kakor je bilo že omenjeno, uvrstitev frazemov v določene rubrike ni bila enostavna. Na primer frazem stopiti na jezik združuje dva pomena: govorjenja in ravnanja. ${ }^{9} \mathrm{~V}$ podobnih primerih sem za določujočo pomensko sestavino izbrala prvo. Pri razpredelitvi frazemov v določene skupine sem si pomagala z razlagami v SSKJ in $\mathrm{s}$ tematskima slovarjema. ${ }^{10}$

\section{A.1 Človek kot živo bitje}

\section{1 Življenjski ciklus}

\subsubsection{Rojstvo}

1. ekspr. iti $v$ Rim 'roditi' 11

2. ekspr. priti na svet 'roditi se'

\subsubsection{Mladost, rast}

3. star. hoditi v krilu 'biti otrok'

\subsubsection{Zrelost}

4. ekspr. zlesti iz plenic/iz povojev 'postati odrasel, samostojen'

\subsubsection{Starost}

5. ekspr. lesti v leta 'počasi se starati'

6. evfem. priti v leta 'postarati se'

\subsubsection{Smrt}

7. ura doteka komu 'kdo bo kmalu umrl'

8. ekspr. iti v krtovo deželo 'umreti'

9. ekspr. iti s tega sveta 'umreti'

10. ekspr. iti v smrt 'umreti'

11. nižje pog., ekspr. iti po gobe 'umreti'

12. evfem. iti//oditi na drugi svet 'umreti'

13. ekspr. iti rakom žvižgat (in ribam gost) 'umreti, ubiti se'

14. vznes. iti v nebeško veselje 'umreti'

15. ekspr. iti (iz hiše) z nogami naprej 'biti mrtev'

16. slabš. iti tja, kjer ni muh 'umreti'

17. šalj. iti/oditi v večna lovišča 'umreti'

18. ekspr. iti s kom h koncu/h kraju 'umreti'

19. evfem. odhajati s sveta 'umirati'

${ }^{8}$ Doslej so bili tako analizirani frazemi govorjenja (Kržišnik 1994, 2007), frazemi s pomenom 'umreti' (Stramljič Breznik 1998) in frazemi s pomenom 'premikati se' (Savelieva 2007)

${ }^{9}$ Prim. E. Kržišnik (1994, 169).

${ }^{10}$ Baranov (1995) in A. Levin-Steinmann (1999).

${ }^{11}$ Frazemi imajo kvalifikatorje, ki so povzeti po SSKJ, nekateri primeri nimajo oznak zaradi odsotnosti le-teh v slovarju. 
20. evfem. oditi med krilatce 'umreti'

21. knjiž. oditi v onstranstvo 'umreti'

22. vznes. oditi $v$ nevrnitev 'umreti'

23. vznes. oditi po večno plačilo 'umreti'

24. vznes. oditi v kraljestvo senc 'umreti'

25. vznes. oditi/odpraviti se na zadnjo pot 'umreti'

26. žarg. oditi v trinajsti bataljon/brigado 'umreti'

27. evfem. vrsta pride na koga 'umreti'

28. evfem. čigava zadnja ura je prišla/prihaja 'kdo je umrl/umira'

29. knjiž. priti v objem smrti 'umreti'

30. evfem. kmalu priti za kom 'umreti'

31. ekspr. priti ob glavo 'biti ubit'

32. star. stopiti pred božji tron 'umreti'

33. evfem. zadnje ure tečejo komu 'kdo bo kmalu umrl'

\section{2 Človeško telo}

\subsubsection{Postava}

34. ekspr. lesti//zlesti $v$ dve gube 'dobivati//dobiti sključeno držo'

35. ekspr. ne priti dosti od tal 'ne zrasti dosti'

\subsubsection{Deli telesa}

\subsection{Počutje}

\subsubsection{Zdravje, moč}

\subsection{2 Šibkost, bolehnost}

\subsubsection{Bolezen}

36. ekspr. iti pod nož 'dati se operirati'

37. poljud. mesec nosi koga 'kdo je mesečnik'

38. evfem. šlo je naprej 'imela je spontani splav'

39. pog. zlesti skupaj 'omedleti'

\subsubsection{Utrujenost}

\subsection{Procesi življenjske delavnosti, naravne potrebe človeka}

\subsubsection{Prehrana}

40. ekspr. vino gre za kom 'kdo se upijani šele nekaj časa po pitju'

41. šalj. pijača/vino komu gre/leze//zleze v lase/v glavo 'kdo se opijanja, postaja pijan'

42. šalj. pijača komu gre/leze v noge 'kdo je tako vinjen, da zelo težko hodi'

43. pog. lesti vkup od lakote 'biti zelo lačen; postajati slaboten, brez moči od lakote'

44. dosti ga nesti 'spiti mnogo alkoholne pijače, ne da bi se upijanil'

45. ekspr. priti na okus kaj komu 'kdo pri kaki stvari začuti zadovoljstvo ob njej'

46. barko voziti 'pijan se opotekati; popivati'

\subsubsection{Spanje}

47. ekspr. hoditi s kokošmi/kurami spat 'hoditi zelo zgodaj spat'

48. šalj. iti pod kožo gledat 'iti spat' 
49. pog. oči komu lezejo skupaj 'postajati zelo zaspan'

50. ekspr. spanec komu leze na oči 'postajati zaspan'

51. ekspr. vleči dreto 'smrčati'

\subsubsection{Spolnost}

52. star. iti po plemenu 'goniti se, pariti se'

\subsubsection{Izločanje}

53. iti na blato 'iztrebiti se'

\subsection{Sposobnost premikanja ${ }^{12}$}

\subsection{Zaznava obdajajočega sveta}

\subsection{Glas, govor}

\subsubsection{Govorjenje}

54. ekspr. gnati (vse) na nož/na ostrino/na špico "vse obravnavati s prepirom'

55. ekspr. goniti svojo 'vztrajno ponavljati svojo trditev; govoriti isto'

56. beseda komu gre/teče (gladko) 'kdo govori z lahkoto'

57. beseda komu ne gre/gre težko z jezika 'kdo nerad, težko kaj pove'

58. iti težko z jezika/iz ust/ne iti z jezika komu 'nerad, težko kaj povedati'

59. pog., ekspr. jahati na vsaki besedi 'zahtevati, da se uporabijo določene besede; iskati v govorjenju, pripovedovanju drugačen smisel, kot v njem je'

60. ekspr. besede komu (enakomerno/počasi) polzijo iz ust 'kdo počasi govori'

61. govoriti, kar pride na jezik 'nič ne pretehtati, ne premisliti, kar govoriti'

62. ekspr. priti iz srca komu kaj 'reči iskreno, prizadeto'

63. ekspr. priti do besede 'začeti govoriti'

\footnotetext{
${ }^{12}$ Frazemi s skupnim pomenom 'premikati se' so obravnavani v prispevku Elene Savelieve Frazemi s pomenom »premikati se«v slovenskem knjižnem jeziku (oddano v objavo). Frazemi tematizirajo različne načine premikanja: hojo (hoditi k nogam), tek (brusiti noge/pete), vožnjo (poganjati/vrteti pedale) in lastnosti premikanja: hitro (brusiti noge) - počasno (hoditi kot polž), težko, okorno, nerodno (hoditi kot staro motovilo) - lahkotno (hoditi kot srna), hrupno (lomastiti kot slon) - tiho (stopati tiho kot mačka), urejeno (iti/hoditi v gosjem redu) - neurejeno (hoditi kot čreda), neestetsko (hoditi kakor/kot medved pleše), previdno (hoditi kot/kakor po jajcih), ponosno (nositi se/hoditi kot/kakor pav) - ponižno (oditi/potikati se/vleči se) kakor potepen/pretepen pes in neodločno premikanje (korak komu omahuje). Tematizirajo tudi začetek premikanja (vzeti pot pod noge), brezciljnost premikanja (iti, kamor noge ponesejo; hoditi, kakor v sanjah), sledenje (komu stati/biti za petami), premikanje ne po določeni poti (iti čez drn in strn), smer premikanja, npr. priti (pot zanese koga) - oditi (dvigniti sidro) - raziti se (raziti se vprek in $v$ šir) - premikati se navzgor (gristi kolena). Frazemi s pomeni 'priti, oditi, raziti se' lahko imajo še dodatne pomene, in sicer oditi zelo hitro (pokazati pete), zbežati (stisniti rep med noge), oditi naskrivaj (čez noč zmanjkati koga); priti hitro (prikaditi jo), v nepravem času (sam hudič prinese koga), razburjeno (pridrveti kot/kakor burja). Razmerje med pomeni sestavin in pomenom frazema je vzpostavljeno z metonimičnimi in primerjalnimi prenosi, tako da je notranja zgradba večine frazemov odprta. Zaprto notranjo zgradbo imajo predvsem frazemi z osebnim zaimkom (kresniti jo). V večini frazemov, ki vsebujejo glagol premikanja (91 od 184 frazemov), je pomen glagola prisoten tudi v celovitem pomenu frazema.
} 
64. ekspr. priti z besedo na dan/na plan 'povedati, kaj misliti'

65. priti/prileteti na jezik komu kaj 'izgovoriti'

66. ekspr. priti iz ust komu kaj 'izreči kaj'

67. ekspr. skočiti//skakati komu v besedo 'prekinjati koga pri govorjenju'

68. pog., ekspr. stopiti komu na jezik 'ukreniti kaj, da kdo preneha negativno govoriti o čem'

69. ekspr. jezik/jeziček komu teče gladko/spretno/kot namazan/kot mlin 'kdo se izraža spretno, z lahkoto'

70. ekspr. beseda komu uide z jezika 'kdo nehote kaj izreče'

71. ekspr. (iz)vleči iz koga besedo/besede 's težavo koga pripraviti, da govori'

72. ekspr. besede komu zletijo iz ust 'kdo hitro, nepričakovano kaj izgovori'

\subsubsection{Krik}

\subsubsection{Molčanje}

73. vznes. kaj nesti (s seboj) v grob 'nikomur ne povedati'

\section{A.2 Notranji svet človeka}

\subsection{Značaj človeka in njegovo izražanje}

\subsubsection{Značaj}

74. ekspr. denar komu ne gre rad/gre nerad iz rok 'kdo je skop'

75. ekspr. iti v nenasitni golt komu kaj 'kdo je zelo lakomen, požrešen'

76. ekspr. pri enem ušesu komu iti noter, pri drugem (pa) ven 1. 'nič si ne zapomniti'

77. ekspr. priti v meso in kri kaj 'postati čigava navada'

\subsubsection{Nravstvene lastnosti}

78. nositi glavo pokonci 'biti ponosen, samozavesten'

79. ekspr. visoko nositi nos 'biti domišljav, prevzeten'

80. ekspr. kdo ne biti vreden, da ga zemlja nosi 'biti slab, ničvreden'

81. lažje koga nositi kot poslušati 'kdo je zelo neprijeten, nadležen'

\subsubsection{Ravnanje}

82. ekspr. (stvar) gnati predaleč 'pretiravati'

83. hoditi/smukati kakor/kot mačka okrog/okoli vrele kaše 'ne upati se lotiti jedra problema'

84. ekspr. iti do zadnjih mej 'storiti vse, kar se da, ne glede na težave, posledice'

85. ekspr. iti/stopati preko trupel 'ravnati skrajno brezobzirno'

86. iti vase 'zamisliti se'

87. ekspr. pri enem ušesu komu iti noter, pri drugem (pa) ven 2. 'ničesar ne ubogati, ne upoštevati'

88. slabš. iti se Francoza 'narediti, delati se brezbrižnega, nevednega in neumnega'

89. ekspr. jadrati z vsemi jadri preko česa 'skušati se čemu kar najhitreje izmakniti'

90. ekspr. previsoko letati 'imeti prevelike zahteve; biti preveč domišljav'

91. ekspr. naganjati komu strah v kosti 'strašiti koga, vznemirjati' 
92. ekspr. na rokah nositi koga 'zelo negovati, razvajati; biti zelo obziren, pozoren do koga'

93. pog., ekspr. nositi kaj samo na jeziku 'govoriti eno, čutiti, ravnati pa drugače'

94. plavati/zaplavati s tokom 'začeti misliti, ravnati tako, kakor misli, ravna večina, vodilni ljudje'

95. pog., ekspr. poganjati ga 'počenjati neumnosti, lahkomiselnosti'

96. knjiž., ekspr. prekoračiti/prestopiti Rubikon 'storiti odločilno dejanje'

97. ekspr. priti k pameti 'začeti bolj premišljeno, razsodno ravnati'

98. ekspr. priti ob pamet 'ne biti sposoben premišljeno, razsodno ravnati'

99. ekspr. ne priti komu do konca 'ne prepričati koga'

100. ekspr. skakati si v lase 'prepirati se; tepsti se'

101. zagnati se v koga kot ose 'jezno, razdraženo se premaknit proti komu'

102. zaleteti se z glavo skozi zid/v zid 'poskušati izsiliti, doseči nemogoče'

103. ekspr. zlesti/priti pod kožo kdo komu 'znati spoznati, predstaviti bistvo človeške narave'

104. ekspr. zlesti v srce kdo komu 'biti vzljubljen'

105. ekspr. znesti//znašati jezo/nejevoljo nad kom 'zaradi jeze, nejevolje zelo neprijazno s kom govoriti, ravnati'

\section{2 Čustva, občutki}

\subsubsection{Psihično stanje}

106. hoditi/drveti kakor/kot v sanjah 1. 'biti zamišljen, duševno odsoten'

107. ekspr. luna koga nosi 'biti zmeden, neuravnovešen'

\subsubsection{Pozitivna čustva}

108. ekspr. skakati//skočiti do stropa 'biti zelo vesel'

\subsubsection{Negativna čustva}

109. preveč si gnati $k$ srcu 'preveč se žalostiti, vznemirjati'

110. ekspr. iti v nos komu kaj 'čutiti se užaljenega, prizadetega'

111. ekspr. lesti//zlesti na kup/vase 'iz zadrege, žalosti, ponižnosti se držati sključeno'

112. ekspr. strah komu lezel/zleze v kosti 'zbati se'

113. pog., ekspr. srce komu pade/uide v hlače 'zbati se, izgubiti pogum'

114. zastar. čigavo srce prepluje žalost 'postati žalosten'

115. ekspr. zagnati vik in krik 'zelo se razburiti za kaj'

116. ekspr. zagnati hrušč in trušč 'zelo se razburiti'

\subsection{4 Čustva-odnosi}

117. ekspr., pren. iti komu na jetra 'dražiti koga, povzročati komu nejevoljo'

118. iti komu na živce 'dražiti koga, povzročati komu nejevoljo'

119. ekspr. kaj komu iti do srca 'koga kaj gane'

120. ekspr. nositi srce na dlani 'vedno očitno kazati svoja čustva'

121. ekspr. nositi srce na jeziku 'zaupati svoja čustva'

122. ekspr. priti komu do živega 'dražiti koga, povzročati komu nejevoljo' 


\subsection{Razum}

\subsubsection{Umske sposobnosti}

123. pog., ekspr. kdo ni po prežganki/prežgani juhi/župi priplaval 'biti bister, prebrisan'

\subsubsection{Pamet}

124. ekspr. hoditi po glavi komu kaj 'dolgo premišljevati o čem; velikokrat misliti na to'

125. ekspr. iti/priti v glavo komu kaj 'spomniti se'

126. star. ne iti iz uma/z uma komu kaj ' kdo česa ne more pozabiti'

127. ne iti iz glave komu kaj 'kdo česa ne more pozabiti'

128. star. ne iti v um/v glavo komu kaj 'težko si zapomniti, težko razumeti'

129. nositi kaj v glavi 'premišljevati'

130. ekspr., pren. po glavi poditi/hoditi komu kaj 'razmišljati'

131. ekspr. priti na pamet komu kaj 'spomniti se česa; pomisliti na kaj'

132. pog. uiti iz glave, iz spomina komu kaj 'ne spomniti se česa več'

\subsubsection{Znanje}

133. hoditi po svetu z odprtimi očmi 'dobro opažati, spoznavati stvari, pojave okrog sebe'

134. star. hoditi za kom 'posnemati koga, zlasti v literaturi'

135. knjiž. iti/priti čemu do jedra 'popolnoma kaj spoznati'

136. ekspr. priti čemu do dna 'popolnoma kaj spoznati'

\subsection{Volja}

\subsection{1 Želja}

137. ekspr. po golih kolenih iti za kom 'na vsak način si koga želeti pridobiti'

\subsubsection{Zahteva}

\section{A.3 Človek kot delavec}

\section{1 Človek v delu}

\subsubsection{Delovni procesi}

138. ekspr. hoditi po kostanj $v$ žerjavico 'opravljati nevarna dela, od katerih imajo drugi koristi'

139. ekspr. iti v klas/v klasje kaj 'uspevati se, uspešno končati'

140. iti kakor po notah/kakor po maslu kaj 'potekati uspešno, brez zapletljajev'

141. nižje pog. iti kakor po žnori kaj 'potekati uspešno, brez zapletljajev'

142. redko iti/potekati kakor po olju/po loju kaj 'potekati uspešno, brez zapetljajev'

143. ekspr. iti kot namazano kaj 'potekati gladko, uspešno, brez ovir, težav'

144. iti gladko od rok kaj 'rešiti hitro, uspešno'

145. ekspr. iti s trebuhom za kruhom 'iskati zaslužek zunaj domačega kraja, domovine'

146. nar. prekmursko iti na krušno 'postati preužitkar'

147. pog. iti čez morje 'oditi v čezmorsko deželo, navadno kot izseljenec na delo' 
148. ekspr. iti čez (veliko) lužo 'iti iskat zaslužka v Ameriko'

149. nar. iti se obesit na zvon 'iti zvonit'

150. ekspr. iti na tanko kaj 'komu se godi slabo'

151. ekspr. iti skozi šivankino uho 'napraviti kaj težko uresničljivega'

152. ekspr. iti z levo roko v desni žep 'lotiti se stvari napačno, neustrezno'

153. pog., ekspr. povleči (ta) kratko 'stvar se za koga konča manj ugodno kot za druge ‘

154. pritiliti na slabše 'komu se godi slabše'

155. ekspr. voda komu v grlo teče 'kdo je v hudi časovni stiski zaradi kakega dela'

156. ekspr., pren. zaiti $v$ škripce 'priti v neprijeten, zapleten položaj'

157. zavoziti jo 'napačno narediti'

158. ekspr. zlesti/stopiti iz (svoje) lupine 'postati dejaven, sproščen'

\subsubsection{Poklicnost, kakovost dela}

159. pog. iti od rok kaj 'opravljati delo hitro, uspešno'

160. ekspr. vodo v morje nositi 'delati kaj odvečnega, nesmiselnega'

161. star. vodo v Savo nositi 'opravljati nepotrebno, nekoristno delo'

162. ekspr. zajahati pegaza 'začeti pesniti'

\subsubsection{Količina dela}

\subsubsection{Organizacija dela}

\subsection{Prosti čas, narodno ustvarjanje}

\subsection{Nedelavnost}

\section{B.1 Č lovek v s et u ljudi}

\subsection{Način življenja}

163. knjiž. bloditi v mraku 'biti v zmoti, nejasnosti; živeti v neznanju'

164. knjiž., ekspr. hoditi na hoduljah 'živeti vzvišen nad resničnostjo, vsakdanjostjo'

165. ekspr. hoditi po zvoženih kolesnicah 'živeti, delati na ustaljen način'

166. ekspr. hoditi po izhojenih potih 'živeti, delati tako, kot je bilo do takrat v navadi'

167. ekspr. tavali v temi 'živeti v nevednosti, neznanju'

\section{2 Človek v skupnosti, kolektivu}

\subsubsection{Odnosi med ljudmi}

\section{Pomoč}

168. pog. iti na roke/na roko 'delati za koga tako, kot želi; pomagati'

169. ekspr. prinesti vse na krožniku/pladnju 'omogočiti, da kdo brez truda kaj doseže'

\section{Nevarnost}

170. ekspr. iti volku v žrelo 'bližati se veliki nevarnosti'

171. pog. iti komu za glavo 'biti v nevarnosti, da koga usmrtijo'

172. pog., ekspr. nositi glavo/kožo naprodaj 'izpostavljati se smrtnim nevarnostim' 
173. pog., ekspr. nositi glavo v torbi 'biti v neprestani življenjski nevarnosti'

174. pog., ekspr. odnesti celo glavo, celo (zdravo) kožo 'nepoškodovan priti iz tepeža, boja'

175. srečno jo odnesti 'nič hudega se komu ne zgodi'

176. pog., ekspr. prinesti celo bučo domov 'nepoškodovan priti iz tepeža, boja'

177. pog., ekspr. dobro, srečno jo zvoziti 'nič hudega se komu ne zgodi'

\section{Kaznovanje, grajanje}

178. pog., ekspr. (pre)poceni jo odnesti 'ne biti huje kaznovan ali poškodovan'

179. ekspr. povleči koga za ušesa 'kaznovati koga s potegljaji za uhelj; kaznovati koga sploh'

180. pog., ekspr. poceni jo zvoziti 'ne biti huje kaznovan ali poškodovan'

\section{Varanje, goljufanje, prevara}

181. ekspr. hoditi/laziti po ovinkih 'pripovedovati tako, da se da le sklepati, kaj je glavni namen povedanega, govorjenja'

182. ekspr. iti komu na led 'dati se prevarati, ukaniti'

183. ekspr. iti/sesti komu na limanice 'dati se prevarati, ukaniti'

184. pog., ekspr. iti komu na lim 'dati se prevarati, ukaniti'

185. ekspr. iti/zaiti komu, čemu v past 'dati se prevarati, ukaniti'

186. iti/hoditi okrog riti v aržet/žep 'govoriti o čem neodkrito, ne naravnost'

187. ekspr. iti se mance/skrivalnice 'ne govoriti, ne ravnati odkrito'

188. ekspr. iti se slepe miši 'ne govoriti, ne ravnati odkrito'

189. ekspr. prepeljati koga žejnega čez vodo 'z zvitim govorjenjem, ravnanjem izmakniti se izpolnitvi zahtev koga'

190. nižje pog. koga okrog prinašati 'goljufati, varati'

191. ekspr. speljati koga na led/v past/na limanice 'prevarati, ukaniti koga'

192. ekspr. vleči//povleči/voditi koga za nos 'varati koga, prevarati, ukaniti'

\section{Dobrikanje}

193. pog. hoditi okrog koga 'prizadevati si pridobiti čigavo naklonjenost; prizadevati si vplivati na koga, prizadevati si dobiti kako korist od koga'

194. pog. iti po dlaki komu 'v vsem komu skušati ustreči, ne nasprotovati'

195. pog., ekspr. lesti komu v zadnjico/nekam 'izkazovati komu pretirano vdanost, prijaznost z namenom pridobiti si naklonjenost'

196. vulg. lesti komu $v$ rit 'izkazovati komu pretirano vdanost, prijaznost $\mathrm{z}$ namenom pridobiti si naklonjenost'

197. vulg., pren. komu pod rep (v čreva) lesti 'prilizovati se komu'

198. ekspr. po kolenih/po trebuhu se plaziti pred kom 'pretirano ponižno se vesti, navadno iz koristoljubja'

199. vulg., pren. vse k riti prinesti komu 'zelo striči komu'

\section{Oviranje}

200. ekspr. stopati/hoditi/priti komu na pot 'ovirati koga pri kaki dejavnosti, delu'

201. ekspr., pren. stopiti komu na rep 'narediti, da kdo ne more opravljati določene dejavnosti, storiti določenega dejanja' 


\section{Ljubezenski odnosi}

202. šalj., pren. hoditi komu v zelje/zelnik 'dvoriti ženi ali dekletu koga; vtikati se v zadeve, kjer ima kdo svoje načrte, namene'

203. ekspr. letati/hoditi/laziti za kom 'osvajati koga'

204. ekspr. nositi roge/rožičke 'čigava žena ima spolne odnose z drugimi moškimi'

205. ekspr. nositi koga v srcu 'biti zaljubljen'

206. ekspr., pren. skakati (skočiti) čez planke 'biti nezvest v zakonu'

207. ekspr. skočiti/skakati/uhajati čez ojnice/čez plot 'biti nezvest v zakonu'

208. pog., ekspr. smukati se okoli/okrog koga 'veliko in rad se družiti s kom; prizadevati si pridobiti čigavo naklonjenost'

Prisluškovanje, obrekovanje idr.

209. pog. nesti naprej 'povedati drugim, ovaditi'

210. pog. v usta nesti/prinesti//nositi/prinašati 'opravljati'

211. pog., ekspr. nositi koga po zobeh 'obrekovati, opravljati koga'

212. star. nositi komu posluške na ušesa 'pripovedovati, kar se izve s prisluškovanjem, poslušanjem'

213. ekspr. prenašati pošte/trače/čenče 'pripovedovati zaupane, zaupne stvari o kom'

214. ekspr. prinašati//prinesti/nesti/znositi komu kaj na uho/nos/ušesa 'povedati, pripovedovati, kar se ne bi smelo'

215. ekspr. priti na uho/ušesa kaj komu 'kdo kaj izvede'

216. ekspr. priti na tapeto 'kritično govorijo o kom'

217. pog. priti v zobe 'biti opravljan'

218. star. vlačiti//vleči koga po zobeh/skozi zobe 'obrekovati, opravljati koga'

219. ekspr. vleči na uho/ušesa 'prisluškovati'

\subsubsection{Sodelovanje ljudi v skupini}

220. star. hoditi od Poncija do Pilata 'poskušati urediti kako stvar v najrazličnejših uradih, pri najrazličnejših odgovornih ljudeh'

221. star. $v$ caker hoditi 'imeti opravka s kom, s čim'

222. ekspr. komu po glavi hoditi 'samovoljno, brezobzirno ravnati s kom'

223. ekspr. oditi z dolgim nosom 'oditi osramočen; ne da bi kaj opravil'

224. ekspr. plezati/splezati po hrbtih drugih 'hoteti doseči uspeh na škodo drugih'

225. ekspr. priti komu v roke 'biti komu podrejen'

226. priti v čigavo oblast 'popolnoma se podrediti čigavi volji, čigavim zahtevam'

227. publ. priti do skupnega jezika 'doseči enakega mnenja o kaki stvari'

228. ekspr. privleči kaj na dan 'opozoriti na časovno odmaknjeno ali pozabljeno, navadno za koga neprijetno stvar'

229. ekspr. vleči/goniti/speljavati vodo na svoj mlin 'govoriti, delati v svojo korist'

\subsubsection{Norme morale, ravnanja in njihova kršitev}

230. ekspr. (globoko) broditi po krvi 'umoriti mnogo ljudi'

231. hoditi jasna pota 'ravnati, delati pravilno v moralnem pogledu' 
232. ekspr. hoditi po krivih potih 'ravnati, delati nepravilno, moralno oporečno'

233. knjiž. hoditi svoja pota 'ne biti dovzeten za vplive'

234. ekspr. jadrati proti vetru 'ravnati, živeti v nasprotju s stališči, nazori okolja'

235. ekspr. laziti po prstih za čigavim hrbtom 'delovati, ukrepati zahrbtno proti komu'

236. pog., ekspr. nositi fano 'biti prvi, zlasti v slabem'

237. ekspr. nositi zastavo/zvonec 'biti prvi, zlasti v slabem'

238. knjiž. nositi (na sebi) Kajnovo znamenje 'biti morilec'

239. ekspr. priti na pravo pot 'začeti živeti pošteno'

240. ekspr. zapeljati koga na kriva pota 'povzročiti, da kdo začne ravnati, delati nepravilno, moralno oporečno'

\subsubsection{Socialni status}

\section{Socialni položaj in materialno stanje}

241. ekspr. bresti//zabresti/zlesti $v$ dolgove 'zelo se zadolževati, zadolžiti se'

242. ekspr. broditi po denarju 'imeti denar v preobilju'

243. ekspr. drveti v pogubo 'hitro se bližati čemu slabemu'

244. ekspr. čigava pot gre navzgor 'imeti prihodnost pred seboj, življenjski uspeh'

245. pog. hoditi h komu na pósodo 'pri kom si izposojati'

246. hoditi od hiše do hiše 'beračiti'

247. iti naprej 'napredovati, razvijati se'

248. pog., ekspr. iti v franže 'propadati, uničevati se'

249. ekspr. iti navzdol 'gospodarsko, moralno, zdravstveno propadati'

250. pog., ekspr. iti k vragu/k hudiču kaj 'propadati' ekspr. iti po zlu kaj 'propadati'

251. ekspr. iti po gobe kaj 'propadati'

252. ekspr. iti rakom žvižgat (in ribam gost) kaj 'biti zaman, brez uspeha'

253. nar. zahodno iti v maloro kaj 'propadati'

254. ekspr. iti/priti v nič/na nič 'propadati/propasti'

255. ekspr. iti rakovo pot kaj 'nazadovati, propadati'

256. ekspr. iti/hoditi/stopati (v korak/vštric), korakati s časom 'prilagajati se razmeram; biti napreden'

257. ekspr. za nohte iti komu 'znajti se v težkem položaju'

258. ekspr. izvleči se iz blata 'rešiti iz težkega položaja'

259. pog. leteti//zleteti na cesto 'koga dajejo iz službe ali iz stanovanja'

260. ekspr. pognati koga na cesto 'dati koga iz službe ali iz stanovanja'

261. ekspr. pognati po grlu kaj 'zapraviti s pijačo, zapiti'

262. ekspr. pognati koga na boben 'spraviti koga/kaj v prisilno dražbo, povzročiti gospodarski propad koga/česa'

263. pog. koga je hudič/vrag pojahal 'imeti zelo neprijetne, hude posledice; propasti'

264. ekspr. koga prehiti čas 'ne prilagoditi se razmeram; ne biti napreden'

265. ekspr. čigava ura pride 'uresničijo se komu želje; kdo si lahko uresniči svoje želje' 
266. ekspr. prijadrati/zajadrati/zapluti v mirnejše vode kaj 'položaj, pogovor se pomiri'

267. ekspr. priplezati do zavidljivega položaja 'v službi s preračunanim vedenjem, ravnanjem dobiti položaj'

268. ekspr. priti na konja 'uspeti, doseči cilj'

269. slabš. priti do korita 'dobiti donosno službo, imeti ugleden položaj'

270. pog., ekspr. priti na kant 'obubožati, gospodarsko propasti'

271. ekspr., pren. priti na boben 'doživeti prisilno dražbo; gospodarsko propasti'

272. priti na beraško palico 'popolnoma obubožati'

273. ekspr., pren. priti na psa 'finančno, materialno propasti; priti v težek, neprijeten položaj'

274. iron. priti daleč 'moralno, gospodarsko propasti'

275. star. priti komu na rame 'kdo mora skrbeti za koga'

276. ekspr. priti do (svojega) kruha 'sam se preživljati, vzdrževati'

277. pog ekspr. priti/zlesti/splezati na zeleno vejo 'gmotno si opomoči'

278. ekspr. priti na svoj račun 'imeti korist'

279. vulg., pren. kuzla skače v rit komu 'kdo je v težkem, neprijetnem položaju, v stiski'

280. ekspr. splavati po vodi kaj 'propasti'

281. ekspr. splavati po grlu kaj 'zapraviti s pijačo, zapiti'

282. knjiž. stopati//stopiti na plan 'izkazovati, uveljavljati se'

283. ekspr. svet se suka/se vrti okoli koga 'vsi skrbijo za koga, komu strežejo'

284. ekspr., pren. med in mleko tečelta kje 'kje je vsega dovolj; kje je zelo dobro'

285. pren., ekspr. vzpenjati se po družbeni/socialni lestvi/lestvici 'prihajati na družbeno, hierarhično višje mesto, položaj’

286. ekspr. zapoditi/spoditi koga iz službe 'odpovedali službo'

287. pog. daleč jo zavoziti 'moralno, gospodarsko propasti'

288. ekspr. zlesti na kup kaj 'podreti se, razpasti'

289. ekspr. zlesti/izvleči se/priti iz težav 'rešiti se iz neugodnega položaja'

\section{3 Človek v družini}

\subsubsection{Starši in otroci}

290. ekspr. pognati koga čez prag 'napoditi od doma'

\subsubsection{Zakonci}

\subsubsection{Daljni sorodniki}

\subsubsection{Poroka}

291. priti praznih rok ( $k$ hiši) 'v zakon ne prinesti denarja, premoženja'

292. ekspr., pren. skočiti/stopiti v zakonski jarem 'poročiti se'

293. star., mn., pren. skočiti/stopiti v (zakonske) ojnice 'poročiti se'

294. ekspr. zajadrati v zakonski pristan 'poročiti se' 


\subsubsection{Odsotnost družine}

\section{4 Človek in država}

\subsubsection{Socialna podpora}

\subsubsection{Vojska}

295. iti v žold 'iti k vojakom'

\section{B.2 Človekvsvetustvari}

296. zastar. hoditi v priklad komu kaj 'za koga kaj primerno, ugodno'

297. pog. hoditi narobe, navzkriž kaj 'povzročati težave'

298. ekspr. iti v čigavo škodo kaj 'imeti škodo'

299. redko iti križem navzkriž kaj 'iti narobe'

300. ekspr. iti na nož kaj 'kaj se obravnava nepopustljivo ostro'

301. ekspr. iti iz rok v roke kaj 'kaj hitro menja uporabnika, lastnika'

302. ekspr. iti svojo pot kaj 'kaj se razvija, poteka normalno, mirno'

303. ekspr. iti za med kaj 'zelo lahko, zelo dobro se prodajati'

304. ekspr. iti od ust do ust kaj 'širiti se (hitro) med ljudmi'

305. bibl. izganjati/preganjati hudiča z belcebubom 'preganjati manjše zlo z večjim'

306. knjiž. polzeti iz rok kaj 'kaj izgubljati'

307. pog. priti prav komu kaj 'komu kaj koristi, pomaga'

308. priti med ljudi kaj 'razvedeti se, postati splošno znan'

309. ekspr. priti na dan 'razvedeti se'

310. priti/priplavati na površje kaj 'postati znan, javen'

311. priti do (1) 'zgoditi se, nastati, pojaviti se'

312. priti do (2) 'začeti posedovati, dobiti'

313. ekspr. uiti pred nosom kaj 'ko je kdo že zelo blizu čemu'

314. vleči se kot (kurja) čreva kaj 'zelo se vleči'

315. ekspr. zapluti v stare vode kaj 'nič se ne spremeni'

\section{B.3 Človekin religija $a^{13}$}

316. iti na božjo pot 'iti na romanje'

\section{Sklepne ugotovitve}

Frazemi z glagolsko sestavino premikanja so zelo različni v svojem pomenu. Tematizirajo lahko najrazličnejše pojme, npr. smrt (iti v krtovo deželo, iti po gobe), propadanje (kaj gre rakovo pot, kaj splava po vodi), človeške medsebojne odnose (hoditi komu po glavi, hoditi komu v zelnik, iti komu na jetra), položaj v družbi (priti do korita), govorjenje (hoditi po ovinkih), čustvovanje (srce je komu ušlo v hlače). Posamezne rubrike v slovenščini nimajo primerov, npr. »zaznava obdajajočega sveta«; »prosti čas, narodno ustvarjanje «; »nedelavnost«; »narava in človek«; »prostor in čas človekovega bivanja«. Predpostavljamo, da glagoli premikanja niso določljivi $\mathrm{v}$ frazemih, ki pomenijo zgoraj navedene tematike. Nekatere rubrike so predstavljene z majhnim številom frazemov, npr. »človeško telo«; počutje«; »volja«; »človek v

\footnotetext{
${ }^{13}$ Rubriko »človek in religija« je dodala avtorica tega prispevka.
} 
družini«; »človek in država«. Največ frazemov z glagolsko sestavino premikanja je v rubrikah »smrt«, »govorjenje«, »delovni procesi«, »odnosi med ljudmi« in »socialni status «.

Skoraj vsi glagoli premikanja $\mathrm{v}$ frazemih izgubijo svoj prvotni pomen premikanja in dobijo frazeološko vezan pomen. Le v nekaj frazemih glagol premikanja delno ohrani svoj prvotni pomen (npr. hoditi s kokošmi/kurami spat 'iti spat zelo zgodaj', iti pod kožo gledat 'iti spat', iti na blato 'iztrebiti se', iti čez (veliko) lužo 'iti iskat zaslužka v Ameriko'). Razmerje med pomeni sestavin in pomenom frazema je vzpostavljeno s primerjalnimi, metonimičnimi in metaforičnimi prenosi. Vendar celoviti pomen frazemov ohranja neko razmerje do prostobesednozveznega izhodišča, tj. motivacijske podobe. Pri dobesednem prebiranju frazema si ponavadi predstavimo situacijo in prikličemo v spomin prvotni pomen glagola premikanja oz. lastnost, ki je za to situacijo določujoča. Na primer pri frazemu beseda komu uide z jezika pri glagolu uiti se izpostavijo določevalni semi 'hitro', 'nepričakovano, 'neopazno'. Večina glagolov, ki nastopajo v frazemih, je osnovnih, tudi predponskih (gnati, iti, hoditi, leteti, letati, nesti, nositi, voditi, plavati, nositi, odnesti, oditi, prinesti, priti, povleč $i$, uiti, zvoditi idr.) Ostali glagoli so s specifičnim pomenom, npr. bloditi, bresti, dirjati idr. Prevladujejo osnovni glagoli, in sicer so zastopani vsi glagoli razen peljati, jezditi, tekati. Najbolj pogost je glagol iti (85 pojavitev), sledijo mu priti (55), hoditi (29), nositi (22), zlesti (14), lesti (12), oditi (10). Nekateri frazemi imajo druge glagolske sestavine pomenskega polja premikanja. Na primer namesto glagola gnati v frazemu gnati (vse) na nož/na ostrino/na špico, sem v korpusu Nova beseda našla primere samo z glagolom iti. Velikokrat se pojavljajo predponske oblike izhodiščnih glagolov ali njihove vidske različice, npr. v frazemu skakati//skočiti do stropa nastopata glagola poskakovati, poskočiti; frazem srce komu pade/uide $v$ hlače je v korpusu potrjen z glagolom padati: srce pa mu je padalo $v$ hlače pred ženskami ${ }^{14}$ frazem vzpenjati// vzpeti se po družbeni/socialni lestvi/lestvici je $\mathrm{v}$ korpusu zastopan $\mathrm{z}$ glagolom povzpeti in celo $\mathrm{z}$ glagolom plezati. $\mathrm{V}$ nekaterih primerih je namesto nedeterminiranega glagola determiniran, npr. hoditi po kostanj v žerjavico in iti po kostanj v žerjavico. Do spremembe glagolov pride večinoma v primerjalnih frazemih. Iz korpusa se vidi tudi zastopanost glagolov premikanja $\mathrm{v}$ določenih frazemih glede glagolov drugega pomenskega polja. Na primer pri frazemu iti z glavo skozi zid/v zid je bilo najdenih več pojavitev z glagolama riniti in siliti in zelo malo z glagolom iti. Enako pri frazemu iti do srca, kjer sta $\mathrm{v}$ korpusu bila najpogostejša glagola seči in zaboleti. Na podlagi korpusnih podatkov lahko ugotovim, da je v uporabi več glagolov premikanja, kot jih je navedenih v SSKJ.

Strukturna analiza frazemov z glagolsko sestavino kaže, da so glagoli, ki nastopajo $\mathrm{v}$ frazemih, polnopomenski. Pri večini frazemov je levo vezljivostno mesto zasedeno z vršilcem dejanja, ki je lahko človek ali stvar, npr. oditi po večno plačilo, iti v klas/v klasje kaj. Najobsežnejša je skupina glagolskih frazemov, kjer prevladujeta strukturi Glag - Predl BZ (stopiti komu na jezik, jahati na vsaki besedi) v prvi skupini (mesto osebka je zapolnjeno z vršilcem dejanja, nosilcem stanja oz. lastnosti) in Sam

${ }^{14}$ Glede na to, da ni slovenskega frazeološkega slovarja, ki bi predpisal normativno rabo frazema, ne morem dokončno reči, ali je to napačna raba. 
- Glag - Predl BZ (voda komu v grlo teče, kuzla skače v rit komu), v drugi (mesto osebka je zapolnjeno s sestavimo frazema, nosilec stanja ali lastnosti je na desnem vezljivostnem mestu). Manj je primerjalnih frazemov (iti kakor po notah/kakor po maslu kaj) in frazemov s strukturo Glag - Zaim (poganjati ga, zavoziti jo).

\section{Literatura}

Bańczerowski, J. (2000). A halál mint kultúrfogalom a magyar és lengyel nyelvben. URL: http://nyelvor.c3.hu/period/1242/124206.htm

Bańczerowski, J. (2007). A család fogalma a volág magyar nyelvi képében. URL: http://nyelvor.c3.hu/period/1312/131209.pdf

Bitehtina, G. A., Judina, L. P. (1985). Sistema raboty po teme »Glagoly dviženija«. Moskva: Russkij jazyk.

Gantar, Polona (2003). Stalnost in spremenljivost frazema v slovarju. Współczesna polska i stoweńska sytuacja językowa. Opole. 209-223.

Gantar, Polona (2007). Stalne besedne zveze v slovenščini: korpusni pristop. Ljubljana

Jakop, Nataša (2002). Pragmatični frazemi: opredelitev in razvrstitev. Magistrsko delo. Ljubljana.

Jakop, Nataša (2005). Tipologija oblikoslovnih, skladenjskih in pomenskih značilnosti slovenskih pragmatičnih frazemov. Doktorska disertacija. Ljubljana.

Jakop, Nataša (2006). Pragmatična frazeologija. Ljubljana.

Jevdokimova, E. V. (1986). Frazeologizmy s glagolami dviženija v sostave semantičeskogo pol'a dviženija. Issledovanija po semantike. Semantika slova $i$ frazeologizma. Ufa. 123-131.

Kabanova, N. M. (1996). Semantičeskie polja vo frazeologii. Problemy frazeologičeskoj semantiki. Sankt-Peterburg. 107-115.

Kržišnik, Erika (1987/88). Frazeološko gradivo v Slovarju slovenskega knjižnega jezika. Slava 2, št. 2. 143-162.

Kržišnik, Erika (1994). Slovenski glagolski frazemi (ob primeru frazemov govorjenja). Doktorska disertacija. Ljubljana.

Kržišnik, Erika (1998). Frazeologija pri pouku slovenščine kot tujega jezika, Skripta 2. Zbornik za učitelje slovenščine kot drugega/tujega jezika. 27-45.

Kržišnik, Erika (2001). Frazemi s strukturo »glagol + osebni zaimek« v slovenskem jeziku. Frazeologija slowianska. Opole. 239-248.

Kržišnik, Erika (2007). »Metafore«, v katerih govorimo v slovenščini frazeološkokonceptualnometaforična analiza frazemov govorjenja. Frazeologija v jezikoslovju in drugih vedah. Ljubljana. 183-203.

Mirsaetova, L. (2004). Obraz čeloveka vo frazeologičeskoj kartine mira v tatarskom i russkom jazykah. Doktorska disertacija. Kazan'.

Nikitina, T. G. (1995). K voprosu o klassifikacionnoj sheme frazeologičeskogo ideografičeskogo slovarja. Voprosy jazykoznanija 2. Moskva. 68-82.

Stramljič Breznik, Irena (1999). Frazemi s pomenom »umreti« v SSKJ. Prispevki iz slovenskega besedoslovja, Zora 7, Maribor, 264-284. 
Stramljič Breznik, Irena (2000/01). Komunikacijski ali sporočanjski frazemi. Jezik in slovstvo 46, št. 5. 191-200.

Stramljič Breznik, Irena (2006), Pojmovanja in poimenovanja besednih združb v slovenistiki, Filologija 46-47, 285-300.

Stramljič Breznik, Irena (2007), Družina v slovenskih pregovorih in frazemih. Erika Kržišnik in Wofgang Eismann (ur.): Frazeologija v jezikoslovju in drugih vedah. Ljubljana: Filozofska fakulteta, Oddelek za slovenistiko, 251-266.

Telia, V. N. (1995). Slovar' obraznyh vyraženij russkogo jazyka.

Telia, V. N. (1996). Russkaja frazeologija. Semantičeskij, pragmatičeskij $i$ lingvokul turologičeskij aspekty. Moskva: Škola »Jazyki russkoj kultury«.

Toporišič, Jože (2000). Slovenska slovnica. Maribor.

Žele, Andreja (2001). Vezljivost v slovenskem jeziku. Ljubljana: Založba ZRC.

\section{Slovarji}

Baranov, O. S. (1995). Ideografičeskij slovar'russkogo jazyka.

Keber, Janez (2003). Frazeološki slovar slovenskega jezika: poskusni zvezek. Ljubljana.

Korpus Nova beseda http://bos.zrc-sazu.si

Levin-Steinmann, Anke (1999). Thematisches phraseologisches Wörterbuch der russischen Sprache: Charakterisierung und Beschreibung des Menschen. Wiesbaden.

Slovar slovenskega knjižnega jezika z Odzadnjim slovarjem slovenskega jezika in Besediščem slovenskega jezika z oblikoslovnimi podatki: Elektronska izdaja na plošči CD-ROM. (1998). Ljubljana.

Prispelo avgusta 2008, sprejeto septembra 2008

Received August 2008, accepted September 2008

\section{Glagoli premikanja v frazemih slovenskega knjižnega jezika}

Razprava obravnava frazeme z glagolsko sestavino premikanja, ki so bili zbrani iz Slovarja slovenskega knjižnega jezika. Frazemi se navezujejo na človeka, zato so bili na podlagi klasifikacije Nikitine (1995), ki je v svoji razpravi natančno predstavila tematsko skupino »človek«, razvrčeni v pet osnovnih tematskih skupin »človek kot živo bitje«, »notranji svet človeka«, »človek kot delavec«, »človek v svetu ljudi« in »človek v svetu stvari«. Skupine imajo več podskupin. Pregledano gradivo kaže, da frazemi tematizirajo najrazličnejše pojme, npr. smrt (itiv krtovo deželo, iti po gobe), propadanje (iti rakovo pot kaj, splavati po vodi kaj), človeške medsebojne odnose (hoditi komu po glavi, hoditi komu v zelnik, iti komu na jetra), položaj v družbi (priti do korita), govorjenje (hoditi po ovinkih), čustvovanje (srce je komu ušlo v hlače). Posamezne skupine v slovenščini nimajo primerov, npr. »zaznava obdajajočega sveta«; »prosti čas, narodno ustvarjanje «; »nedelavnost«; »narava in človek «; »prostor in čas človekovega bivanja«. Predpostavljamo, da glagoli premikanja niso določljivi $\mathrm{v}$ frazemih, ki pomenijo zgoraj navedene tematike. Nekatere rubrike so predstavljene 
z majhnim številom frazemov, npr. »človeško telo«; »počutje«; »volja«; »človek v družini«; »človek in država«. Največ frazemov z glagolsko sestavino premikanja je v rubrikah »smrt«, »govorjenje«, »delovni procesi«, »odnosi med ljudmi« in »socialni status«. Skoraj vsi glagoli premikanja v frazemih izgubijo svoj prvotni pomen premikanja in dobijo frazeološko vezan pomen. Le v nekaj frazemih glagol premikanja delno ohrani svoj prvotni pomen (npr. hoditi s kokošmi/kurami spat 'iti spat zelo zgodaj', iti pod kožo gledat 'iti spat', iti na blato 'iztrebiti se', iti čez (veliko) lužo 'iti iskat zaslužka v Ameriko'). Razmerje med pomeni sestavin in pomenom frazema je vzpostavljeno s primerjalnimi, metonimičnimi in metaforičnimi prenosi. Vendar celoviti pomen frazemov ohranja neko razmerje do prostobesednozveznega izhodišča, tj. motivacijske podobe. Pri dobesednem prebiranju frazema si ponavadi predstavimo situacijo in prikličemo $\mathrm{v}$ spomin prvotni pomen glagola premikanja oz. lastnost, ki je za to situacijo določujoča. Večina glagolov premikanja s skupnim pomenom premagovanja poti, ki nastopajo v frazemih, je osnovnih, tudi predponskih (gnati, iti, hoditi, leteti, letati, nesti, nositi, voditi, plavati, nositi, odnesti, oditi, prinesti, priti, povleč $i$, uiti, zvoditi idr.) Ostali glagoli so s specifičnim pomenom, npr. bloditi, bresti, dirjati idr.

\section{Verbs of Motion in Phrasemes in Standard Slovene}

The paper deals with phrasemes containing verbs of motion gathered from the Dictionary of Standard Slovene. The phrasemes are connected with human beings, therefore on the basis of Nikitina's 1995 classification, the group "human being" is divided into five basic thematic groups: "human being as such", "the inner world of the human being", "a human being as a worker", "the human being in the world of people", and "the human being in the world of things". These groups are in turn divided into smaller subgroups. The material surveyed shows that the phrasemes thematicize highly heterogeneous notions, e.g., death (iti v krtovo deželo, iti po gobe), failure (iti rakovo pot kaj, splavati po vodi kaj), interpersonal relations (hoditi komu po glavi, hoditi komu v zelnik, iti komu na jetra), social status (priti do korita), speech (hoditi po ovinkih), emotions (srce je komu ušlo v hlače). Certain groups have no examples in Slovene, e.g., "perception of the world", "leisure time, folk creativity", "idleness", "nature and the human being", "space and time in human experience". We assume that verbs of motion are not essential for phrasemes in the thematic field just adduced. Some of the rubrics are represented by a small number of phrasemes, e.g., "the human body", "feeling", "will", "the person in the context of family", "the person and the state". Most phrasemes with verbs of motion are in the categories "death", "speech", "work processes", "human relations", and "social status". Almost all the verbs of motion lose their original meanings of motion and acquire a meaning bound up with the phrase. Only in some phrasemes do the verbs of motion retain their original meaning (e.g., hoditi s kokošmi/kurami spat 'to go to sleep early', iti pod kožo gledat 'to go to sleep', iti na blato 'to make a bowel movement', iti čez (veliko) lužo 'to go to America to earn a living'). The relationship between the elements and the semantics of the phrasemes as a whole are juxtaposed with similes, metonyms and metaphors. However, the holistic meaning of the phrases preserves the relation- 
ship to the bare syntagm, i.e., its motivating notions. In a word-for-word reading of a phraseme we generally imagine a situation and call into memory the original meaning of a verb of motion or the property that is determinative of the situation. The majority of verbs of motion with the general meaning of traversing a path, which occurs in phrasemes both with simplex and prefixed verbs (gnati, iti, hoditi, leteti, letati, nest , nositi, voditi, plavati, nositi, odnesti, oditi, prinesti, priti, povleči, uiti, zvoditi, etc.) The remaining verbs have more specific denotations, e.g., bloditi, bresti, dirjati. 